\title{
Glutathione in Ovarian Cancer: A Double-Edged Sword
}

\author{
Sofia C. Nunes ${ }^{1,2}$ and Jacinta Serpa $1,2, *$ (D) \\ 1 Centro de Estudos de Doenças Crónicas (CEDOC), NOVA Medical School/Faculdade de Ciências Médicas, \\ Universidade Nova de Lisboa, Campo Mártires da Pátria 130, 1169-056 Lisboa, Portugal; \\ sofia.nunes@nms.unl.pt \\ 2 Unidade de Investigação em Patobiologia Molecular do Instituto Português de Oncologia de Lisboa \\ Francisco Gentil (IPOLFG), Rua Prof. Lima Basto, 1099-023 Lisboa, Portugal \\ * Correspondence: jacinta.serpa@nms.unl.pt
}

Received: 30 May 2018; Accepted: 25 June 2018; Published: 26 June 2018

\begin{abstract}
Glutathione (GSH) has several roles in a cell, such as a reactive oxygen species (ROS) scavenger, an intervenient in xenobiotics metabolism and a reservoir of cysteine. All of these activities are important in the maintenance of normal cells homeostasis but can also constitute an advantage for cancer cells, allowing disease progression and resistance to therapy. Ovarian cancer is the major cause of death from gynaecologic disease and the second most common gynaecologic malignancy worldwide. In over 50 years, the overall survival of patients diagnosed with epithelial ovarian cancer has not changed, regardless of the efforts concerning early detection, radical surgery and new therapeutic approaches. Late diagnosis and resistance to therapy are the main causes of this outcome, and GSH is profoundly associated with chemoresistance to platinum salts, which, together with taxane-based chemotherapy and surgery, are the main therapy strategies in ovarian cancer treatment. Herein, we present some insights into the role of GSH in the poor prognosis of ovarian cancer, and also point out how some strategies underlying the dependence of ovarian cancer cells on GSH can be further used to improve the effectiveness of therapy.
\end{abstract}

Keywords: ovarian cancer; cancer metabolism; glutathione; cysteine; chemoresistance; platinum based drugs

\section{Introduction}

In 1888, Rey-Pailhade described philothion, a molecule that reacted spontaneously with sulphur, producing hydrogen sulphide [1,2]. Years later, Hopkins concluded that philothion and glutathione (GSH) were identical and, after several studies, in 1935, its structure was established as a tripeptide, composed of glutamic acid, cysteine and glycine $[1,3]$. Since then, countless papers have been published regarding GSH's role in health and disease.

GSH is found in Gram-negative bacteria and eukaryotes, being rare in Gram-positive bacteria. In mainly Archaea or amitochondrial eukaryotes, GSH is not generally found, leading Copley and Dhillon to suggest that bacteria transferred the genes for GSH biosynthesis to eukaryotes via the progenitor of mitochondria [4]. However, the evolutionary history of GSH biosynthesis genes is more complex. Data suggested that these genes evolved separately and their spread possibly involved events of horizontal gene transfer, including a transfer from an alpha-proteobacterium to a plant and also convergent evolution [4], as bacterial and eukaryotic proteins share a common structural fold but have very divergent sequences. Glutamic acid, cysteine and glycine are the building blocks of GSH, whose biosynthesis involves two ATP-requiring enzymes: glutamate cysteine ligase (GCL) and GSH synthetase. The first enzyme catalyses the formation of a dipeptide bond between the $\gamma$-carboxylate 
of glutamic acid and the amino group of cysteine and the latter catalyses the subsequent formation of a peptide bond between the cysteinyl carboxylate of $\gamma$-Glu-Cys and the amino group of glycine. Besides substrate availability, GCL is the rate-limiting enzyme in GSH synthesis, which presents two different subunits: the catalytic subunit (GCLC), containing the active site responsible for the bond formation between the amino group of cysteine and the $\gamma$-carboxyl group of glutamic acid, and the modifier subunit (GCLM) that interacts with GCLC, increasing the catalytic efficiency of GCLC [5]. GSH synthesis occurs in the cells cytosol. In theory, all cells are capable of synthesizing GSH; however, the liver present the highest capacity for its efflux, transporting GSH to the plasma and inter- and intra-organs [6]. Its degradation occurs extracellularly and it is catalysed by $\gamma$-Glutamyl transpeptidase and dipepdidase. The first enzyme leads to cysteineglycine production, which is subsequently cleaved by dipeptidase, producing cysteine and glycine [7].

Regarding GSH functions, Estrela [8] exhaustively described its impact on cell biology:

"GSH acts as a reducing agent and an antioxidant, is involved in the metabolism of xenobiotics and different cell molecules, is a free-radical scavenger, has a role in cell-cycle regulation and microtubular-related mechanisms, is a physiological reservoir of Cys, regulates $\mathrm{Ca}^{2+}$ homeostasis, regulates protein function and gene expression via thiol-disulphide exchange reactions, modulates lymphocyte functions and immune responses, and participates in the mitochondrial mechanisms that link opening of the permeability transition pore complex and activation of cell death" [8].

So, it is well known that GSH not only plays a main role in intracellular redox balance [3] but is also pivotal in cellular processes such as cell differentiation, proliferation and apoptosis [8-10]. Moreover, GSH was associated with resistance to ionizing radiation and drug-induced cytotoxicity [8,10-13]. However, radiotherapy is not commonly used to treat ovarian cancer.

As it plays so many important roles in cell biology, the linkage of GSH deregulation with disease is obvious. In fact, GSH metabolism impairment has been associated with several diseases such as cancer, kwashiorkor, seizure, Alzheimer's and Parkinson's disease, liver disease, cystic fibrosis, sickle cell anaemia, acquired immunodeficiency disease syndrome (AIDS), heart attack, stroke, diabetes $[8,14,15]$, several mitochondrial disorders [16], Niemann Pick type $C$ disease [17] and progressive multiple sclerosis $[18,19]$.

Here we will review the role of GSH in cancer, focusing on ovarian cancer, the major cause of death from gynaecologic disease and the second most common gynaecologic malignancy worldwide [20,21]. This molecule is profoundly associated with platinum salt resistance, one of the main treatment strategies for ovarian cancer, and is thus of extreme importance as a potential threat to ovarian cancer cells.

\section{Ovarian Cancer-An Overview}

Ovarian cancer is the major cause of death from gynaecologic disease and the second most common gynaecologic malignancy worldwide [20,21], especially due to late diagnosis and resistance to therapy [22]. Epithelial ovarian cancer (EOC) includes most malignant ovarian neoplasms [23] and is composed of different diseases that can be classified based on morphologic and molecular genetic features: serous (OSC; low and high grade), endometrioid (EC), clear cell (OCCC) and mucinous (MC) carcinomas. Each histological subtype was already associated with a specific genetic and transcriptional signature: low-grade OSC generally comprising BRAF, KRAS, NRAS, Erb-B2 Receptor Tyrosine Kinase 2 (ERBB2) mutations; high-grade OSC comprising mutations in Tumour Protein P53 (TP53), BRCA1/2, Neurofibromin 1 (NF1), RB Transcriptional Corepressor 1 (RB1), Cyclin Dependent Kinase 12 (CDK12), homologous recombination repair of DNA damage defective in approximately $50 \%$ of high grade serous cancers and alterations in signalling pathways such as PI3/Ras/Notch/ FoxM1. EC subtypes involve mutations in AT-Rich Interaction Domain 1A (ARID1A), Phosphatidylinositol-4,5-Bisphosphate 3-Kinase Catalytic Subunit Alpha (PI3KCA), Phosphatase And Tensin Homolog (PTEN), Protein Phosphatase 2 Scaffold Subunit Alpha (PPP2R1 $\alpha$ ), and mismatch repair deficiency; OCCC subtype comprises de novo expression of HNF1 $\beta$ [24,25] and ARID1A, 
PI3KCA, PTEN, Catenin Beta 1 (CTNNB1) and PPP2R1 $\alpha$ mutations; MC comprises tumours with mutations in KRAS and high frequency of ERBB2 amplification with overexpression of mucin-coding genes [26,27].

OSC is the most prevalent histological type [22], with diagnosis at an advanced stage in approximately $70 \%$ of patients [28]. In contrast, OCCC is a rather uncommon histological type of ovarian cancer that is frequently diagnosed at an initial stage [29]. However, OCCC tumours present markedly different clinical behaviours compared to other EOC subtypes, presenting, generally, a poor prognosis given the intrinsic chemoresistance to conventional platinum, or taxane-based therapy [29], which, together with surgery, constitute the standard care for ovarian cancer [30]. Importantly, therapy based on platinum salts involves ROS-mediated apoptosis [31-33]. Cisplatin and carboplatin are highly reactive molecules that bind to RNA, DNA and proteins, leading to the formation of adducts $[30,33]$. The nuclear DNA adducts are thought to be mainly responsible for cisplatin cytotoxicity (Figure 1), inducing cell death as a result of DNA damage and inhibition of replication and transcription $[30,33]$. Marullo et al. reported a role of cisplatin also in ROS production (Figure 1) driven by protein synthesis impairment [33]. Paclitaxel cytotoxicity is associated with its binding to intracellular $\beta$-tubulin, which leads to microtubule stabilization, G2-M arrest and apoptosis [30,34]. However, Alexandre et al. also reported that Paclitaxel exposure induces ROS production, as $\mathrm{H}_{2} \mathrm{O}_{2}$ accumulation showed to be an early and crucial step in paclitaxel cytotoxicity [32].

Despite initial response to treatment, $85 \%$ of advanced ovarian cancer patients suffer from disease recurrence [35]. Moreover, in over 50 years, the overall survival of patients diagnosed with epithelial ovarian cancer has not changed, regardless of efforts aimed at early detection, radical surgery and new therapeutic approaches [36]. Therefore, we will focus on the role of GSH in mediating resistance to the pro-oxidative chemotherapy used in ovarian cancer.

A

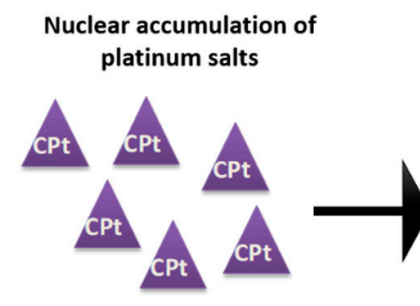

B

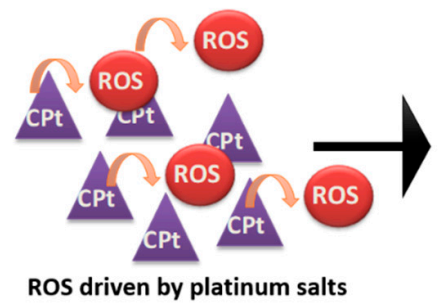
Formation of ROS adducts
with DNA

Formation of platinum salts adducts with DNA

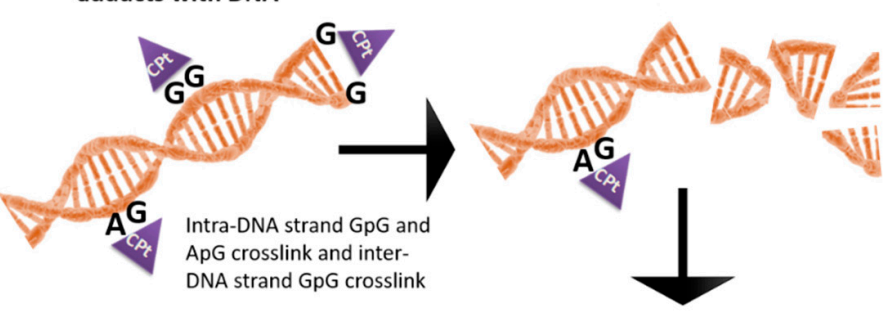

Cell death

Induction of DNA damage
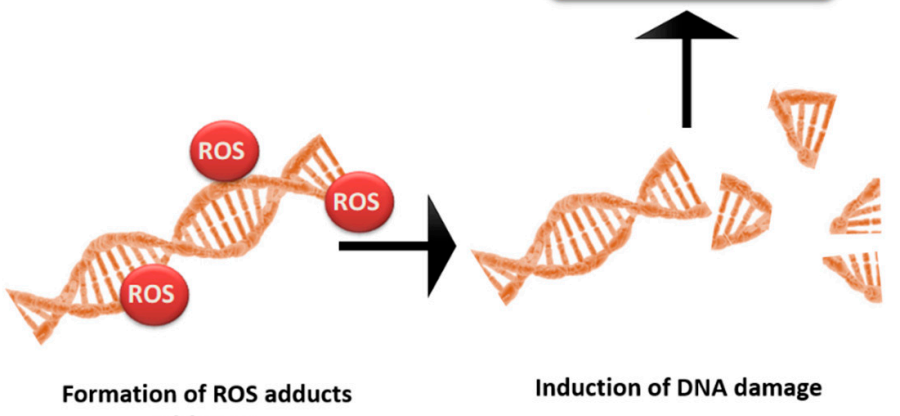

Induction of DNA damage

Figure 1. Mechanism of action of platinum salts. Platinum salts cause cancer cells' death through two mechanisms: (A) direct covalent bonds (adducts) with DNA helix, provoking DNA breaks, and (B) the generation of reactive oxygen species (ROS) through chemical interaction with the organic components of the cell, namely proteins. Despite disturbing the metabolic equilibrium of the cell, these ROS will establish adducts with DNA, inducing DNA damage. Based on Benhar et al. [37] and Chaney et al. [38]. 


\section{GSH-Mediated Platinum-Based and Taxane-Based Chemoresistance in Ovarian Cancer}

Cisplatin and carboplatin are platinum analogues in which carboplatin presents a similar efficacy to cisplatin, but with significantly less toxicity [30,39]. GSH is known to mediate resistance to both cisplatin and carboplatin through several mechanisms such as drug uptake reduction and increased intracellular drug detoxification/ inactivation (Figure 1), increased DNA repair and inhibition of apoptosis drug-induced oxidative stress [40-43]. Specifically in ovarian cancer, although with some controversy $[44,45]$, several reports already associated high GSH levels or glutathione S-transferase P1 (GSTP1) activity with cisplatin or carboplatin resistance [46-53]. More recently, Sawers et al. [54] have shown that the stable deletion of GSTP1 significantly and selectively increased sensitivity both to cisplatin and carboplatin in A2780 ovarian cancer cells [54]. Crawford and Weerapana reported a dichlorotriazine-containing compound (LAS17) that selectively and irreversibly inhibited GSTP1 activity, thus providing a promising cancer therapeutic target [55]. In addition, Chen et al. have shown that the overexpression of the microRNA miR-133b increased ovarian cancer cell sensitivity to both cisplatin and paclitaxel by decreasing glutathione GSTP and multidrug resistance protein 1 (MDR1) expression [56]. Importantly, Lopes-Coelho et al. [57] were able to find differences among ovarian cancer histotypes in terms of carboplatin resistance and GSH levels. They found that OCCC cells were more resistant to carboplatin than OSC cells, and that the inhibition of GSH production by BSO sensitized these cells to carboplatin, both in vitro and in vivo [57]. Those results highlight that ovarian cancer is a complex disease in which each histotype presents unique features in terms of thiol metabolism and response to chemotherapeutic agents that should be taken into account in the clinical context.

Paradoxically, concerning the role of GSH in paclitaxel resistance, Liebmann et al. have shown that the depletion of cellular GSH by L-BSO resulted in increased resistance to taxol in MCF-7 and A549 cells [58]. However, Medeiros et al. reported that patients with ovarian cancer, who are carriers of glutathione-S-transferase class $\mu$ (GSTM1)-null genotype or carriers of non-GSTM1-wt/GSTT1-wt genotypes, when treated with both paclitaxel and cisplatin, present higher mean survival time [59], suggesting a role for GSH in paclitaxel resistance also.

\section{GSH Antagonists in Ovarian Cancer}

Given the crucial role of GSH in ovarian cancer chemoresistance, efforts to antagonize its effects on cancer cells have already been developed. So far, different strategies have been reported, like inhibiting GSH biosynthesis, using GSH analogues or drugs targeting S-glutathionylation of proteins.

In the context of ovarian cancer, the effect of agents that lead to GSH depletion has already been addressed. Hong and colleagues have reported the effect of a phytochemical $\beta$-phenylethyl isothiocyanate (PEITC), on ROS accumulation and consequent UPR-mediated apoptosis in SKOV3 ovarian cancer cell line [60]. This drug is involved in cysteine modification of side chains in GST, leading to its irreversible inhibition. Importantly, this drug did not affect normal ovarian epithelial cells or peripheral blood mononuclear cells [60]. However, the authors also reported that the addition of $N$-acetyl-L-cysteine, a ROS scavenger, was able to revert the PEITC-induced cell death [60]. These results show that one possible mechanism of resistance to this drug would be the upregulation of alternative antioxidant responses capable of counteracting this ROS accumulation, such as thioredoxins. Similar findings of PEITC on apoptosis induction in OVCAR3 cells were also reported [61].

BSO was another drug involved in the inhibition of GSH production reported in the ovarian cancer context. BSO is a specific inhibitor of GCL, a critical enzyme in GSH biosynthesis. As already mentioned, Lopes-Coelho et al. have reported that the inhibition of GSH production by BSO sensitized OCCC cells to carboplatin exposure, both in vitro and in vivo [57]. Interestingly, in a mice model of breast cancer and in cell lines including lymphoma, glioblastoma, and non-small-cell lung carcinoma, Harris et al. reported that the GSH antioxidant pathway was required for cancer initiation but not for its progression due to the existence of alternative antioxidant pathways. They have shown that the depletion of GSH driven by BSO was able to prevent the malignant transformation but, at the disease 
onset, only the combined inhibition of GSH and thioredoxin antioxidant pathways led to synergistic cancer cell death, both in vitro and in vivo [62]. Those results support the idea that cancer cells might evolve resistance mechanisms in other antioxidant pathways in order to counteract oxidative stress, thus being able to survive. In a clinical context, BSO was shown to be a chemosensitizer but with no clinical advantages due to the severe adverse effects, thus clinical trials are no longer being developed [63].

Some studies have also tested the effect of natural compounds. Wang and colleagues explored the role of gossypol, a phenolic aldehyde present in cotton and tropical plants, in ovarian cancer cells and have shown that apoptosis was related to GSH depletion and changes of the thiol redox state in several proteins [64]. Importantly, they observed changes in redox-sensitive cysteine residues in proteins involved in metabolism homeostasis and stress responses [64].

Recently, 3-bromopyruvate (3-BP), known as an antagonist of lactate and pyruvate, was also found to form GSH conjugates, leading to its depletion and allowing chemoresistance reversion in several cancer types [65]. Gandham and colleagues, using SKOV-3 spheroids, showed 3-MP cytotoxicity in the ovarian cancer context [66], thus being a general anti-cancer strategy with promising results also in ovarian cancer [65].

Acetaminophen, known as paracetamol, was also reported to deplete GSH, contributing to chemoresistance reversion [65]. Using SKOV3, Wu and colleagues have demonstrated the benefits of acetaminophen as a co-adjuvant drug, improving cisplatin and paclitaxel efficacy [67]. They also reported the enhanced effect of cisplatin combined with this drug on reducing tumour recurrence in a SKOV3 subcutaneous xenograft mouse model [67]. Very recently, Lian et al. reported the long-lasting activation of paracetamol and its cytotoxic effects in SKOV3 cells using a tyrosinase-MOF nanoreactor, an enzymatic nanoreactor based on metal-organic frameworks (MOFs) [68]. This strategy may allow, simultaneously, the achievement of higher cancer cell selectivity with consequent decreased systemic toxicology and an increase in the half-lives of the activating enzymes, leading to lasting paracetamol activation [68].

GSH analogues were also reported in ovarian cancer. Telcyta (TLK286) is a GSH analogue that, when metabolized by GSTP1-1, releases a reactive tetrakis (chloroethyl) phosphorodiamidate fragment and a glutathione analogue vinyl sulphone that, following activation, triggers the stress response pathway, leading to cellular apoptosis induction [69]. Telcyta has been tested in Phase II and III clinical trials for ovarian cancer treatment, as a monotherapy regime or in combination with other chemotherapeutic agents [63]. However, a Phase III (NCT00350948) randomized study of Telcyta and doxorubicin in platinum refractory ovarian cancer patients (ASSIST-5) showed that Telcyta led to poorer outcomes than standard strategies [63]. Mechanisms such as increased/decreased rates of drug efflux/influx could explain the failure of those strategies.

Drugs that target S-glutathionylation—a reversible mechanism of protein regulation [70]—have already been developed in ovarian cancer. Anthracyclines, such as doxorubicin, induce cyclical redox reactions, leading to S-glutathionylation of cellular proteins [71]. However, according to a systematic review and meta-analysis of randomized trials in the ovarian cancer context, a liposome-encapsulated formulation of doxorubicin did not improve the overall survival of ovarian cancer patients when compared to other strategies in all phases of disease [72]. This study also reported a marginal advantage in progression-free survival—only in platinum-sensitive patients and as a second-line treatment [72]. Those results support the existence of a link between platinum-based therapy resistance and S-glutathionylation-induced resistance.

NOV-002 consists of other inducer of S-glutathionylation tested in ovarian cancer. However, in chemotherapy-resistant ovarian cancer patients (NCT00345540), NOV-002 in combination with carboplatin failed to reach its aim, and thus was withdrawn [63].

The observed failure of drugs targeting S-glutathionylation in clinical trials regarding ovarian cancer might be explained by resistance mechanisms such as increased/decreased rates of drug 
efflux/influx as cellular redox status affects transporters' function or resistance to apoptosis through caspase-3 S-glutathionylation [73].

\section{The Paradox of Antioxidants as Co-Adjuvants of Pro-Oxidative Drugs}

So far, the studies concerning GSH-mediated resistance to conventional chemotherapy have led to the hypothesis that targeting redox balance via GSH deprivation in combination with pro-oxidant therapies should be effective in cancer treatment. However, antioxidant supplementation during chemotherapy was also rationalized as a way to counteract the deleterious effects of cancer-induced antioxidant depletion [74]. In fact, it has been suggested that antioxidants could have a beneficial effect as co-adjuvants of chemotherapy in patients with ovarian cancer. Di Re et al. [75] reported that GSH addiction is safe, well-tolerated and very effective in ovarian cancer patients with bulky disease subject to high-dose cisplatin administration [75]. Confirming this study, years later, Smyth and colleagues [76] demonstrated in a clinical trial that GSH addition together with cisplatin was less toxic and increased the quality of life of advanced-stage ovarian cancer patients [76]. However, in these studies, parameters such as the median survival of patients, tumour recurrence and tumour growth rate were not assessed; only quality of life parameters were assessed, so it is unclear if GSH addition is in fact safe. Ladas et al. reviewed the efficacy and safety of antioxidant use during cancer treatment and concluded that there is a lack of evidence that individual antioxidant vitamin supplements reduce the toxicity associated with anticancer therapies [74]. Probably the antioxidant intake during chemotherapy improves the quality of life of patients, because the adverse effects of cytotoxics are minimized, but the cytotoxic effectiveness on cancer cells is also reduced, compromising the overall efficacy of the oxidative therapy.

The wide variation in extracellular (e.g., $2-20 \mu \mathrm{mol} / \mathrm{L}$ in plasma) and intracellular $(0.5-10 \mathrm{mM})$ GSH concentrations in animal cells [15] led to the notion that this leads to a large difference in reducing potential between the intracellular and extracellular compartments that could be exploited for triggered intracellular delivery of several bioactive molecules [77]. Given that tumour tissues are highly reducing and hypoxic compared to normal tissues and present higher GSH concentrations $[77,78]$, the reducible bioconjugates could be valuable for tumour-specific drug delivery [77], as it was described for GSH-responsive micelles that improves paclitaxel delivery [79-83]. This led to the development of a targeted intracellular delivery system of paclitaxel based on redox-sensitive conjugates of hyaluronic acid-deoxycholic acid, which was tested in human breast adenocarcinoma cell lines [84]. It was proven that cancer cells were able to uptake these micelles by endocytosis and, in tumour-bearing mice, redox-sensitive micelles presented a much higher tumour-targeting capacity than in the control mice treated with paclitaxel without micelles [84]. Yan et al. also reported a novel polymer-paclitaxel conjugate based on a disulphide linker with a high Paclitaxel loading amount capacity, using HEK293 and HeLa cells [80]. More recently, Pei et al. reported GSH-responsive nanovesicles that exhibited improved paclitaxel solubility and effective cellular uptake in HeLa and HepG2 cells [81]. As far as we know, in an ovarian cancer context, those micelles have not been tested yet, but we predict that the response of ovarian cancer cells to those micelles would differ between histological types, in which OCCC cells that are more dependent on thiol metabolism would be even more suitable for this delivery system.

Taken together, there is not enough evidence to support the use of GSH as a co-adjuvant of chemotherapeutic drugs. However, evidence suggests that cancer cells' dependence on GSH can be further exploited in ovarian cancer cells to trigger anti-cancer drug delivery to ovarian cancer cells, which could be a promising strategy in fighting ovarian cancer.

\section{GSH as a Cysteine Reservoir}

One of the most important functions of GSH is the storage of cysteine, given its high extracellular instability that rapidly auto-oxidizes to cystine (the oxidized dimer form of cysteine) [8].

The contribution of cysteine to cancer cells' survival due to hydrogen sulphide $\left(\mathrm{H}_{2} \mathrm{~S}\right)$ generation [85-90] and as a precursor of GSH $[7,57,91]$ has been explored. In mammalian cells, 
$\mathrm{H}_{2} \mathrm{~S}$ is mainly generated via enzymatic pathways and from the metabolism of L-cysteine by the catalysis of three key enzymes: cystathionine $\beta$-synthase (CBS), cystathionine $\gamma$-lyase (CSE) and by 3-mercapto-pyruvate sulfurtransferase (MpST), accompanied by cysteine aminotransferase (CAT) [92]. Besides MpST, in conjunction with CAT [93], CSE [94] and CBS [85,86] were also associated with $\mathrm{H}_{2} \mathrm{~S}$ generation and mitochondrial ATP production (Figure 2).

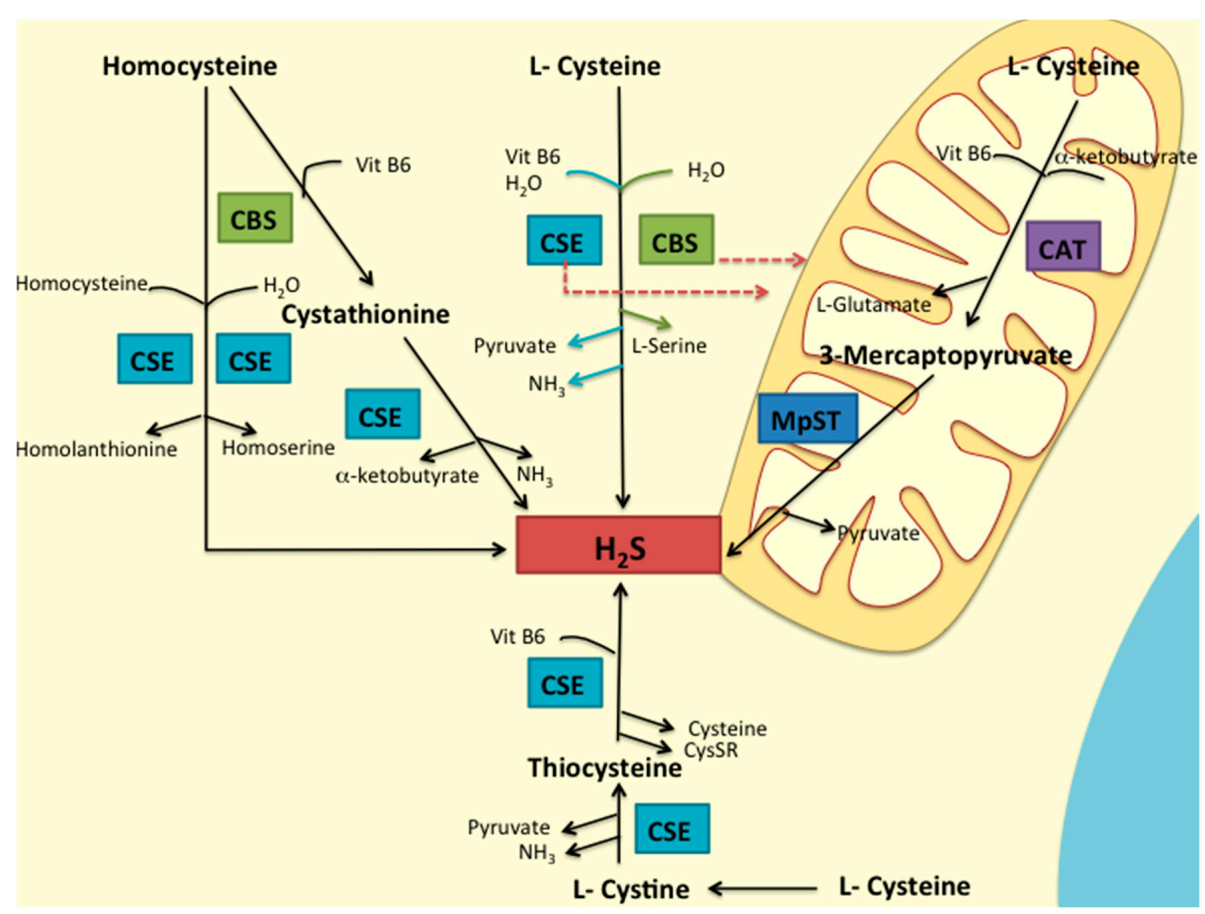

Figure 2. Pathways of $\mathrm{H}_{2} \mathrm{~S}$ production in mammalian cells. $\mathrm{H}_{2} \mathrm{~S}$ is synthesized from homocysteine or cysteine by the enzymes CBS and CSE, or by the sequential activity of CAT and MpST. In physiological conditions, $\mathrm{CBS}$ and CSE produce cytosolic $\mathrm{H}_{2} \mathrm{~S}$, whereas, in case of cellular stress, the enzymes can be relocated to the mitochondria, supporting CAT/MpST activities. Adapted from Wang [92] and Olson et al. [95].

In the context of ovarian cancer, Bhattacharyya et al. found a role of CBS in promoting ovarian tumour growth, drug resistance and cellular bioenergetics [85]. Recently, Cochrane and colleagues, through a proteomic screen, reported that CSE overexpression was consistent in OCCC and rare in endometrioid and high-grade serous ovarian cancer [96]. This fact suggests that the worse prognosis of OCCC could be due to a higher dependence of cancer cells on cysteine metabolism. Moreover, Poisson et al., through a metabolomics analysis, reported that platinum-sensitive and -resistant ovarian cancer cells presented significant differences involving cysteine and methionine metabolism [97]. They reported that 5-methylthioadenosine, cystathione, cysteine, cysteine sulphinic acid and methionine decreased in the resistant cells compared to the sensitive cells, while alanine, aspartate, reduced GSH, S-formyl-L-methionine and pyruvate were increased in resistant cells [97].

Okuno et al. [98] reported that the transport system $\mathrm{x}_{\mathrm{c}}{ }^{-}(\mathrm{xCT})$, involved in cystine and glutamate transport, was associated with intracellular GSH level and with cisplatin resistance in human ovarian cancer cell lines. Wang and colleagues explored the role of ovarian cancer cells' microenvironment and showed that fibroblasts decreased the nuclear accumulation of platinum in cancer cells through glutathione and cysteine release. On the other hand, they demonstrated that $\mathrm{CD} 8^{+} \mathrm{T}$ cells counteracted this resistance by changing GSH and cystine metabolism in fibroblasts [99]. These results highlight the importance of cysteine in GSH-mediated resistance to cisplatin (Figure 3), as intracellular cysteine is a rate-limiting precursor for GSH synthesis [98]. Moreover, cysteine is the thiol component of GSH and the reversible thiolation of proteins was already associated with the regulation of several metabolic 
processes such as enzyme activity, transport activity, signal transduction and gene expression [10]. Several proteins-such as RAt Sarcoma vírus (Ras) protein, Jun N-terminal kinase (JNK)-2, Activator protein 1 (AP-1), Nuclear Factor-kappaB (NFkB), protein kinase C (PKC), caspase, thioredoxin and tumour protein 53 (p53) [10,100]—which are known to have important roles in ovarian cancer [101-112], are regulated by thiol oxidation [100]. Interestingly the oxidation of cys residues of p53 induces protein inactivation, which accounts for carcinogenesis [100]. Visscher et al. reported that many oncogenic mutations consist of an insertion of a novel cysteine in the protein sequence [113]. They also reported that acquired cysteines account for at least $12 \%$ of all activating mutations found in Kirsten ras oncogene (KRAS) in cancer, and $88 \%$ of mutations in fibroblast growth factor receptor (FGFR). They suggested that acquired cysteines often play a role in tumourigenesis [113], probably by contributing to tumour suppressor genes' inactivation and oncogenes' activation.

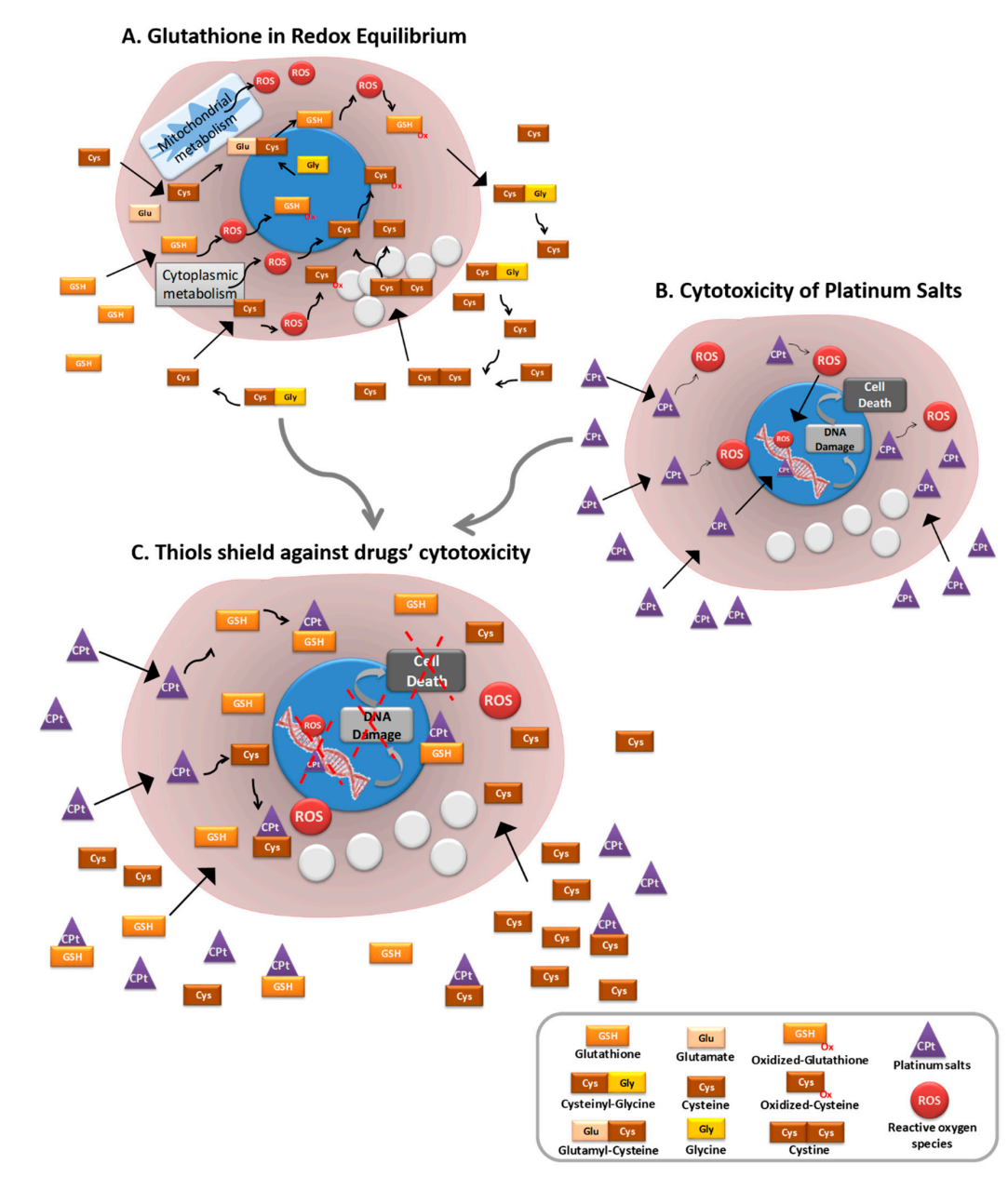

Figure 3. Gluthathione serves as a shield to protect ovarian cancer cells from conventional platinum drugs. (A) Glutathione is a pivotal player in the maintenance of redox equilibrium, which allows for homeostatic metabolic flux in a cell. Cysteine is the thiol component of glutathione and can also work as a ROS scavenger. (B) Platinum-salt-based drugs are commonly used to treat cancer; their cytotoxic mechanisms induce DNA damage, directly through covalent bonds (adducts) or through the generation of reactive oxygen species (ROS). (C) Cancer cells whose metabolism relies on thiols are better protected against platinum-salt-derived drugs. Glutathione and cysteine can bind to platinum salts, abrogating their cytotoxic effect and protecting cancer cells from DNA damage and consequently from death. Thiols allow for the regulation of several metabolic processes central to cancer cells, thus allowing cancer cells' survival in a stressful and detrimental environment. 
Interestingly, Moheel and colleagues reported an active methylene quinuclidinone compound derived from the prodrug APR-246 (PRIMA-1 ${ }^{\mathrm{MET}}$ ), which not only binds to cysteine residues in mutant p53, restoring its wild-type conformation, but also binds to cysteine from GSH, leading to decreased intracellular free GSH concentrations [114]. This compound was able to restore the sensitivity to both cisplatin and doxorubicin of p53-mutant drug-resistant ovarian cancer cells [114].

Together, ovarian cancer cells' dependence on GSH might be mainly due to its component cysteine, as it has a role in GSH-mediated and $\mathrm{H}_{2} \mathrm{~S}$-mediated chemoresistance, promotes redox balance and allows for the regulation of several metabolic processes central to cancer cells, thus permitting cancer cells' survival in a stressful and detrimental environment (Figure 3).

Our studies on ovarian cancer metabolic adaptive features, accounting for cell fitness upon stressful conditions and chemoresistance, have shown that cysteine is beneficial to cancer cells. Hypoxia is a common condition in the cancer microenvironment, and it is well established that cancer cells that are capable of surviving hypoxia will be more prone to progression. We have shown that cysteine is a facilitator for cancer cells' adaption to hypoxia and also to carboplatin, and for most ovarian cancer cell lines this adaptive capacity relies on CD133+ cells, putatively cancer stem cells $[115,116]$.

With the exception of GSH, our data revealed increased thiol levels in peripheral blood from patients with ovarian tumours (benign and malignant) compared to healthy individuals. Interestingly, peripheral blood protein-S-cysteinylation levels were able to distinguish healthy donors from patients with ovarian neoplasms (benign and malignant) and total free cysteine levels distinguished benign tumours from malignant tumours [115], showing that cysteine levels are putative biomarkers for ovarian cancer's early diagnosis. As late diagnosis is one of the most important barriers accounting for poor outcome and high mortality, our findings pave the path for an early diagnosis method.

\section{Conclusions}

GSH plays many important roles in cell biology, and evidence suggests that cancer cells are especially dependent on it. Strategies that aim to deplete cellular GSH or target S-glutathionylation of proteins have failed so far. However, exploiting GSH to trigger the delivery of anti-cancer drugs to cancer cells is promising in ovarian cancer treatment. In addition, as GSH is an important cysteine storage, targeting this amino acid's uptake by cancer cells could be another promising strategy to fight cancer, as cysteine allows for not only GSH-mediated but also $\mathrm{H}_{2} \mathrm{~S}$-mediated chemoresistance. Moreover, cysteine is the GSH component responsible for the reversible thiolation of proteins that impact the regulation of several metabolic processes that are central to cancer cells' sustainability within the tumour microenvironment. Taken together, targeting GSH, especially through its component cysteine, could be a promising tool to fight ovarian or other types of cancer. Inhibitors of cysteine transporters like sulfasalazine are already used in the context of other diseases such as Crohn's disease and rheumatoid arthritis. This review supports the concept of "teaching old drugs new tricks," as this drug could also be a valuable tool in the context of ovarian cancer treatment.

Author Contributions: S.C.N.-Wrote the main part of the manuscript and discussed the latest version. J.S.- Supervised and corrected the manuscript and discussed the latest version.

Funding: This research group is supported by Fundação para a Ciência e Tecnologia (FCT) (PhD ProRegeM program, PD/BD/105893/2014, FCT fellowship, PD/BD/105768/2014). iNOVA4Health-UID/Multi/04462/2013, a program financially supported by Fundação para a Ciência e Tecnologia / Ministério da Educação e Ciência, through national funds and co-funded by FEDER under the PT2020 Partnership Agreement is acknowledged.

Conflicts of Interest: The authors declare no conflict of interest.

\section{References}

1. Meister, A. On the discovery of glutathione. Trends Biochem. Sci. 1988, 13, 185-188. [CrossRef]

2. De Rey-Pailhade, J. Sur un corps d'origine organique hydrogénant le soufre á froid. CR Acad. Sci. 1888, $106,1683-1684$. 
3. Meister, A. Glutathione metabolism and its selective modification. J. Biol. Chem. 1988, 263, 17205-17208. [PubMed]

4. Copley, S.D.; Dhillon, J.K. Lateral gene transfer and parallel evolution in the history of glutathione biosynthesis genes. Genome Biol. 2002, 3. [CrossRef]

5. Franklin, C.C.; Backos, D.S.; Mohar, I.; White, C.C.; Forman, H.J.; Kavanagh, T.J. Structure, function, and post-translational regulation of the catalytic and modifier subunits of glutamate cysteine ligase. Mol. Asp. Med. 2009, 30, 86-98. [CrossRef] [PubMed]

6. Ookhtens, M.; Kaplowitz, N. Role of the liver in interorgan homeostasis of glutathione and cyst(e)ine. Semin. Liver Dis. 1998, 18, 313-329. [CrossRef] [PubMed]

7. Balendiran, G.K.; Dabur, R.; Fraser, D. The role of glutathione in cancer. Cell Biochem. Funct. 2004, 22, 343-352. [CrossRef] [PubMed]

8. Estrela, J.M.; Ortega, A.; Obrador, E. Glutathione in cancer biology and therapy. Crit. Rev. Clin. Lab. Sci. 2006, 43, 143-181. [CrossRef] [PubMed]

9. Sies, H. Glutathione and its role in cellular functions. Free Radic. Biol. Med. 1999, 27, 916-921. [CrossRef]

10. Traverso, N.; Ricciarelli, R.; Nitti, M.; Marengo, B.; Furfaro, A.L.; Pronzato, M.A.; Marinari, U.M.; Domenicotti, C. Role of Glutathione in Cancer Progression and Chemoresistance. Oxid. Med. Cell. Longev. 2013, 2013, 1-10. [CrossRef] [PubMed]

11. Calvert, P.; Yao, K.S.; Hamilton, T.C.; O'Dwyer, P.J. Clinical studies of reversal of drug resistance based on glutathione. Chem. Biol. Interact. 1998, 111-112, 213-224. [CrossRef]

12. Arrick, B.A.; Nathan, C.F. Glutathione Metabolism as a Determinant of Therapeutic Efficacy: A Review. Cancer Res. 1984, 44, 4224-4232. [PubMed]

13. Meister, A. Glutathione deficiency produced by inhibition of its synthesis, and its reversal; Applications in research and therapy. Pharmacol. Ther. 1991, 51, 155-194. [CrossRef]

14. Townsend, D.M.; Tew, K.D.; Tapiero, H. The importance of glutathione in human disease. Biomed. Pharmacother. 2003, 57, 145-155. [CrossRef]

15. Wu, G.; Fang, Y.; Yang, S.; Lupton, J.R.; Turner, N.D. Glutathione Metabolism and Its Implications for Health. Environ. Health 2004, 134, 489-492. [CrossRef] [PubMed]

16. Enns, G.M.; Moore, T.; Le, A.; Atkuri, K.; Shah, M.K.; Cusmano-Ozog, K.; Niemi, A.; Cowan, T.M. Degree of Glutathione Deficiency and Redox Imbalance Depend on Subtype of Mitochondrial Disease and Clinical Status. PLoS ONE 2014, 9, e100001. [CrossRef] [PubMed]

17. Torres, S.; Matías, N.; Baulies, A.; Nuñez, S.; Alarcon-Vila, C.; Martinez, L.; Nuño, N.; Fernandez, A.; Caballeria, J.; Levade, T.; et al. Mitochondrial GSH replenishment as a potential therapeutic approach for Niemann Pick type C disease. Redox Biol. 2017, 11, 60-72. [CrossRef] [PubMed]

18. Choi, I.; Lee, P.; Denney, D.; Lynch, S. Longitudinal changes of cerebral glutathione levels in patients with secondary progressive multiple sclerosis may reflect the clinical course of disease progression. Mult. Scler. J. 2016. [CrossRef]

19. Choi, I.Y.; Lee, P.; Adany, P.; Hughes, A.J.; Belliston, S.; Denney, D.R.; Lynch, S.G. In vivo evidence of oxidative stress in brains of patients with progressive multiple sclerosis. Mult. Scler. J. 2018. [CrossRef] [PubMed]

20. Siegel, R.; Miller, K.; Jemal, A. Cancer statistics, 2015. CA Cancer J. Clin. 2015, 65, 5-29. [CrossRef] [PubMed]

21. Torre, L.A.; Bray, F.; Siegel, R.L.; Ferlay, J.; Lortet-tieulent, J.; Jemal, A. Global Cancer Statistics, 2012. CA Cancer J. Clin. 2015, 65, 87-108. [CrossRef] [PubMed]

22. Bowtell, D.D. The genesis and evolution of high-grade serous ovarian cancer. Nat. Rev. Cancer 2010, 10, 803-808. [CrossRef] [PubMed]

23. Chan, J.K.; Cheung, M.K.; Husain, A.; Teng, N.N.; West, D.; Whittemore, A.S.; Berek, J.S.; Osann, K. Patterns and progress in ovarian cancer over 14 years. Obstet. Gynecol. 2006, 108, 521-528. [CrossRef] [PubMed]

24. Shen, H.; Fridley, B.L.; Song, H.; Lawrenson, K.; Cunningham, J.M.; Ramus, S.J.; Cicek, M.S.; Tyrer, J.; Stram, D.; Larson, M.C.; et al. Epigenetic analysis leads to identification of HNF1B as a subtype-specific susceptibility gene for ovarian cancer. Nat. Commun 2013, 4. [CrossRef] [PubMed]

25. Mabuchi, S.; Kawase, C.; Altomare, D.A.; Morishige, K.; Sawada, K.; Hayashi, M.; Tsujimoto, M.; Yamoto, M.; Klein-Szanto, A.J.; Schilder, R.J.; et al. mTOR is a promising therapeutic target both in cisplatin-sensitive and cisplatin-resistant clear cell carcinoma of the ovary. Clin. Cancer Res. 2009, 15, 5404-5413. [CrossRef] [PubMed] 
26. Jayson, G.C.; Kohn, E.C.; Kitchener, H.C.; Ledermann, J.A. Ovarian cancer. Lancet 2014, 384, $1376-1388$. [CrossRef]

27. Banerjee, S.; Kaye, S.B. New strategies in the treatment of ovarian cancer: Current clinical perspectives and future potential. Clin. Cancer Res. 2013, 19, 961-968. [CrossRef] [PubMed]

28. Vaughan, S.; Coward, J.I.; Bast, R.C., Jr.; Berchuck, A.; Berek, J.S.; Brenton, J.D.; Coukos, G.; Crum, C.C.; Drapkin, R.; Etemadmoghadam, D.; et al. Rethinking ovarian cancer: Recommendations for improving outcomes. Nat. Rev. 2011, 11, 719-725. [CrossRef] [PubMed]

29. Itamochi, H.; Kigawa, J.; Terakawa, N. Mechanisms of chemoresistance and poor prognosis in ovarian clear cell carcinoma. Cancer Sci. 2008, 99, 653-658. [CrossRef] [PubMed]

30. Agarwal, R.; Kaye, S.B. Ovarian cancer: strategies for overcoming resistance to chemotherapy. Nat. Rev. Cancer 2003, 3, 502-516. [CrossRef] [PubMed]

31. Dasari, S.; Tchounwou, P.B. Cisplatin in cancer therapy: Molecular mechanisms of action. Eur. J. Pharmacol. 2015, 5, 364-378. [CrossRef] [PubMed]

32. Alexandre, J.; Batteux, F.; Nicco, C.; Chéreau, C.; Laurent, A.; Guillevin, L.; Weill, B.; Goldwasser, F. Accumulation of hydrogen peroxide is an early and crucial step for paclitaxel-induced cancer cell death both in vitro and in vivo. Int. J. Cancer 2006, 119, 41-48. [CrossRef] [PubMed]

33. Marullo, R.; Werner, E.; Degtyareva, N.; Moore, B.; Altavilla, G.; Ramalingam, S.S.; Doetsch, P.W. Cisplatin induces a mitochondrial-ros response that contributes to cytotoxicity depending on mitochondrial redox status and bioenergetic functions. PLoS ONE 2013, 8. [CrossRef] [PubMed]

34. Dumontet, C.; Sikic, B.I. Mechanisms of action of and resistance to antitubulin agents: Microtubule dynamics, drug transport, and cell death. J. Clin. Oncol. 1999, 17, 1061-1070. [CrossRef] [PubMed]

35. Ip, C.K.M.; Li, S.; Tang, M.H.; Sy, S.K.H.; Ren, Y. Stemness and chemoresistance in epithelial ovarian carcinoma cells under shear stress. Sci. Rep. 2016, 6. [CrossRef] [PubMed]

36. Kurman, R.J.; Shih, I.M. Molecular pathogenesis and extraovarian origin of epithelial ovarian cancer-Shifting the paradigm. Hum. Pathol. 2011, 42, 918-931. [CrossRef] [PubMed]

37. Benhar, M.; Dalyot, I.; Engelberg, D.; Levitzki, A. Enhanced ROS Production in Oncogenically Transformed Cells Potentiates c-Jun N-Terminal Kinase and p38 Mitogen-Activated Protein Kinase Activation and Sensitization to Genotoxic Stress. Mol. Cell. Biol. 2001, 21, 6913-6926. [CrossRef] [PubMed]

38. Chaney, S.G.; Campbell, S.L.; Temple, B.; Bassett, E.; Wu, Y.; Faldu, M. Protein interactions with platinum-DNA adducts: From structure to function. J. Inorg. Biochem. 2004, 98, 1551-1559. [CrossRef] [PubMed]

39. Aabo, K.; Adams, M.; Adnitt, P.; Alberts, D.S.; Athanazziou, A.; Barley, V.; Bell, D.R.; Bianchi, U.; Bolis, G.; Brady, M.F.; et al. Chemotherapy in advanced ovarian cancer: Four systematic meta-analyses of individual patient data from 37 randomized trials. Advanced Ovarian Cancer Trialists' Group. Br. J. Cancer 1998, 78, 1479-1487. [CrossRef] [PubMed]

40. Siddik, Z.H. Cisplatin: Mode of cytotoxic action and molecular basis of resistance. Oncogene 2003, 7265-7279. [CrossRef] [PubMed]

41. Stewart, D.J. Mechanisms of resistance to cisplatin and carboplatin. Crit. Rev. Oncol. Hematol. 2007, 63, 12-31. [CrossRef] [PubMed]

42. Kelland, L.R. Preclinical perspectives on platinum resistance. Drugs 2000, 59. [CrossRef]

43. Johnson, S.W.; Ozols, R.F.; Hamilton, T.C. Mechanisms of drug resistance in ovarian cancer. Cancer 1993, 71, 644-649. [CrossRef] [PubMed]

44. Ghazal-Aswad, S.; Hogarth, L.; Hall, A.G.; George, M.; Sinha, D.P.; Lind, M.; Calvert, A.H.; Sunter, J.P.; Newell, D.R. The relationship between tumour glutathione concentration, glutathione S-transferase isoenzyme expression and response to single agent carboplatin in epithelial ovarian cancer patients. Br. J. Cancer 1996, 74, 468-473. [CrossRef] [PubMed]

45. Wrigley, E.C.; McGown, A.T.; Buckley, H.; Hall, A.; Crowther, D. Glutathione-S-transferase activity and isoenzyme levels measured by two methods in ovarian cancer, and their value as markers of disease outcome. Br. J. Cancer 1996, 73, 763-769. [CrossRef] [PubMed]

46. Godwin, A.K.; Meistert, A.; Dwyer, P.J.O.; Huangt, C.S.; Hamilton, T.C.; Andersont, M.E. High resistance to cisplatin in human ovarian cancer cell lines is associated with marked increase of glutathione synthesis. Proc. Natl. Acad. Sci. USA 1992, 89, 3070-3074. [CrossRef] [PubMed] 
47. Green, J.A.; Robertson, L.J.; Clark, A.H. Glutathione S-transferase expression in benign and malignant ovarian tumours. Br. J. Cancer 1993, 68, 235-239. [CrossRef] [PubMed]

48. Lewandowicz, G.M.; Britt, P.; Elgie, A.W.; Williamson, C.J.; Coley, H.M.; Hall, A.G.; Sargent, J.M. Cellular Glutathione Content, in Vitro Chemoresponse, and the Effect of BSO Modulation in Samples Derived from Patients with Advanced Ovarian Cancer. Gynecol. Oncol. 2002, 304, 298-304. [CrossRef] [PubMed]

49. Mayr, D.; Pannekamp, U.; Baretton, G.B.; Flens, M.J.; Sch, R.; Gropp, M.; Meier, W.; Di, J. Immunohistochemical Analysis of Drug Resistance- associated Proteins in Ovarian Carcinomas. Pathol. Res. Pract. 2000, 196, 469-475. [CrossRef]

50. Satoh, T.; Nishida, M.; Tsunoda, H.; Kubo, T. Expression of glutathione S-transferase pi (GST-pi) in human malignant ovarian tumors. Eur. J. Obs. Gynecol. Reprod. Biol. 2001, 96, 202-208. [CrossRef]

51. Surowiak, P.; Materna, V.; Kaplenko, I.; Spaczyński, M.; Dietel, M.; Lage, H.; Zabel, M. Augmented expression of metallothionein and glutathione S-transferase pi as unfavourable prognostic factors in cisplatin-treated ovarian cancer patients. Virchows Arch. 2005, 447, 626-633. [CrossRef] [PubMed]

52. Rabik, C.A.; Dolan, M.E. Molecular mechanisms of resistance and toxicity associated with platinating agents q. Cancer Treat. Rev. 2007, 7281, 9-23. [CrossRef] [PubMed]

53. Cheng, X.; Kigawa, J.; Minagawa, Y.; Kanamori, Y.; Itamochi, H.; Okada, M.; Terakawa, N. Glutathione S-transferase-pi expression and glutathione concentration in ovarian carcinoma before and after chemotherapy. Cancer 1997, 79, 521-527. [CrossRef]

54. Sawers, L.; Ferguson, M.J.; Ihrig, B.R.; Young, H.C.; Chakravarty, P.; Wolf, C.R.; Smith, G. Glutathione S-transferase P1 (GSTP1) directly influences platinum drug chemosensitivity in ovarian tumour cell lines. Br. J. Cancer 2014, 111, 1150-1158. [CrossRef] [PubMed]

55. Crawford, L.A.; Weerapana, E. A Tyrosine-Reactive Irreversible Inhibitor for Glutathione S-transferase Pi (GSTP1). Mol. Biosyst. 2016, 12, 1768-1771. [CrossRef] [PubMed]

56. Chen, S.; Jiao, J.W.; Sun, K.X.; Zong, Z.H.; Zhao, Y. MicroRNA-133b targets glutathione S-transferase $\pi$ expression to increase ovarian cancer cell sensitivity to chemotherapy drugs. Drug Des. Dev. Ther. 2015, 9, 5225-5235. [CrossRef]

57. Lopes-Coelho, F.; Gouveia-Fernandes, S.; Gonçalves, LG.; Nunes, C.; Faustino, I.; Silva, F.; Félix, A.; Pereira, S.A.; Serpa, J. HNF1B drives glutathione (GSH) synthesis underlying intrinsic carboplatin resistance of ovarian clear cell carcinoma (OCCC). Tumor Biol. 2016, 37, 4813-4829. [CrossRef] [PubMed]

58. Liebmann, J.E.; Hahn, S.M.; Cook, J.A.; Lipschultz, C.; Mitchell, J.B.; Kaufman, D.C. Glutathione Depletion by L-Buthionine Sulfoximine Antagonizes Taxol Cytotoxicity Glutathione Depletion by L-Buthionine Sulfoximine Antagonizes Taxol Cytotoxicity. Cancer Res. 1993, 53, 2066-2070. [PubMed]

59. Medeiros, R.; Pereira, D.; Afonso, N.; Palmeira, C.; Faleiro, C.; Afonso-Lopes, C.; Freitas-Silva, M.; Vasconcelos, A.; Costa, S.; Osório, T.; et al. Platinum/paclitaxel-based chemotherapy in advanced ovarian carcinoma: Glutathione S-transferase genetic polymorphisms as predictive biomarkers of disease outcome. Int. J. Clin. Oncol. 2003, 8, 156-161. [CrossRef] [PubMed]

60. Hong, Y.H.; Uddin, M.; Jo, U.; Kim, B.; Song, J.; Suh, D.H.; Kim, H.S.; Song, Y.S. ROS accumulation by PEITC selectively kills ovarian cancer cells via UPR-mediated apoptosis. Front. Oncol. 2015, 5, 1-9. [CrossRef] [PubMed]

61. Satyan, K.S.; Swamy, N.; Dizon, D.S.; Singh, R.; Granai, C.O.; Brard, L. Phenethyl isothiocyanate (PEITC) inhibits growth of ovarian cancer cells by inducing apoptosis: Role of caspase and MAPK activation. Gynecol. Oncol. 2006, 103, 261-270. [CrossRef] [PubMed]

62. Harris, I.S.; Treloar, A.E.; Lam, C.; Mak, T.W. Glutathione and Thioredoxin Antioxidant Pathways Synergize to Drive Cancer Initiation and Progression Article Glutathione and Thioredoxin Antioxidant Pathways Synergize to Drive Cancer Initiation and Progression. Cancer Cell 2015, 211-222. [CrossRef] [PubMed]

63. Kirkpatrick, D.L.; Powis, G. Clinically Evaluated Cancer Drugs Inhibiting Redox Signaling. Antioxid. Redox Signal. 2017, 26, 262-273. [CrossRef] [PubMed]

64. Wang, J.; Jin, L.; Li, X.; Deng, H.; Chen, Y.; Lian, Q.; Ge, R.; Deng, H. Gossypol induces apoptosis in ovarian cancer cells through oxidative stress. Mol. Biosyst. 2013, 9. [CrossRef] [PubMed]

65. El Sayed, S.M.; Baghdadi, H.; Zolaly, M.; Al-Maramhy, H.H.; Ayat, M.; Donki, J.G. The promising anticancer drug 3-bromopyruvate is metabolized through glutathione conjugation which affects chemoresistance and clinical practice: An evidence-based view. Med. Hypotheses 2017, 100, 67-77. [CrossRef] [PubMed] 
66. Gandham, S.K.; Talekar, M.; Singh, A.; Amiji, M.M. Inhibition of hexokinase-2 with targeted liposomal 3-bromopyruvate in an ovarian tumor spheroid model of aerobic glycolysis. Int. J. Nanomed. 2015, 10, 4405-4423. [CrossRef]

67. Wu, Y.J.; Neuwelt, A.J.; Muldoon, L.L.; Neuwelt, E.A. Acetaminophen Enhances Cisplatin- and Paclitaxel-mediated Cytotoxicity to SKOV3 Human Ovarian Carcinoma. Anticancer Res. 2013, 33, 2391-2400. [PubMed]

68. Lian, X.; Huang, Y.; Zhu, Y.; Fang, Y.; Zhao, R.; Joseph, E.; Li, J.; Pellois, J.P.; Zhou, H.C. Enzyme-MOF Nanoreactor Activates Nontoxic Paracetamol for Cancer Therapy. Angew. Chem. Int. Ed. 2018, 57, 5725-5730. [CrossRef] [PubMed]

69. Kavanagh, J.J.; Gershenson, D.M.; Choi, H.; Lewis, L. Multi-institutional phase 2 study of TLK286 (TELCYTATM, a glutathione S-transferase P1-1 activated glutathione analog prodrug) in patients with platinum and paclitaxel refractory or resistant ovarian cancer. Int. J. Gynecol. Cancer 2005, 286, 593-600. [CrossRef] [PubMed]

70. Tew, K.D.; Townsend, D.M. Redox platforms in cancer drug discovery and development. Curr. Opin. Chem. Biol. 2011, 15, 156-161. [CrossRef] [PubMed]

71. Montero, A.J.; Jassem, J. Cellular redox pathways as a therapeutic target in the treatment of cancer. Drugs 2011, 71, 1385-1396. [CrossRef] [PubMed]

72. Staropoli, N.; Ciliberto, D.; Botta, C.; Fiorillo, L.; Grimaldi, A.; Lama, S.; Caraglia, M.; Salvino, A.; Tassone, P.; Tagliaferri, P. Pegylated liposomal doxorubicin in the management of ovarian cancer: A systematic review and metaanalysis of randomized trials. Cancer Biol. Ther. 2014, 15, 707-720. [CrossRef] [PubMed]

73. Liu, Y.; Li, Q.; Zhou, L.; Xie, N.; Nice, E.C.; Zhang, H.; Huang, C.; Lei, Y. Cancer drug resistance: Redox resetting renders a way. Oncotarget 2016, 7, 42740-42761. [CrossRef] [PubMed]

74. Ladas, E.J.; Jacobson, J.S.; Kennedy, D.D.; Teel, K.; Fleischauer, A.; Kelly, K.M. Antioxidants and cancer therapy: A systematic review. J. Clin. Oncol. 2004, 22, 517-528. [CrossRef] [PubMed]

75. Di Re, F.; Bohm, S.; Oriana, S.; Spatti, G.B.; Zunino, F. Efficacy and safety of high-dose cisplatin and cyclophosphamide with glutathione protection in the treatment of bulky advanced epithelial ovarian cancer. Cancer Chemother. Pharmacol. 1990, 25, 355-360. [CrossRef] [PubMed]

76. Smyth, J.F.; Bowman, A.; Perren, T.; Wilkinson, P.; Prescott, R.J.; Quinn, K.J.; Tedeschi, M. Glutathione reduces the toxicity and improves quality of life of women diagnosed with ovarian cancer treated with cisplatin: Results of a double-blind, randomised trial. Ann. Oncol. 1997, 8, 569-573. [CrossRef] [PubMed]

77. Meng, F.; Hennink, W.E.; Zhong, Z. Reduction-sensitive polymers and bioconjugates for biomedical applications. Biomaterials 2009, 30, 2180-2198. [CrossRef] [PubMed]

78. Kuppusamy, P.; Li, H.; Ilangovan, G.; Cardounel, A.J.; Zweier, J.L.; Yamada, K.; Krishna, M.C.; Mitchell, J.B. Noninvasive Imaging of Tumor Redox Status and Its Modification by Tissue Glutathione Levels 1. Cancer Res. 2002, 62, 307-312. [PubMed]

79. Li, J.; Huo, M.; Wang, J.; Zhou, J.; Mohammad, J.M.; Zhang, Y.; Zhu, Q.; Waddad, A.Y.; Zhang, Q. Redox-sensitive micelles self-assembled from amphiphilic hyaluronic acid-deoxycholic acid conjugates for targeted intracellular delivery of paclitaxel. Biomaterials 2011. [CrossRef] [PubMed]

80. Yan, Q.; Yang, Y.; Chen, W.; Hu, J.; Yang, D. Construction of polymer-Paclitaxel conjugate linked via a disulfide bond. Mater. Sci. Eng. C 2016, 58, 580-585. [CrossRef] [PubMed]

81. Pei, Q.; Hu, X.; Zhou, J.; Liu, S.; Xie, Z. Glutathione-responsive paclitaxel dimer nanovesicles with high drug content. Biomater. Sci. 2017, 5, 1517-1521. [CrossRef] [PubMed]

82. Geldenhuys, W.; Mbimba, T.; Bui, T.; Harrison, K.; Sutariya, V. Brain-targeted delivery of paclitaxel using glutathione-coated nanoparticles for brain cancers. J. Drug Target. 2011, 19, 837-845. [CrossRef] [PubMed]

83. Yin, S.; Huai, J.; Chen, X.; Yang, Y.; Zhang, X.; Gan, Y.; Wang, G.; Gu, X.; Li, J. Intracellular delivery and antitumor effects of a redox-responsive polymeric paclitaxel conjugate based on hyaluronic acid. Acta Biomater. 2015, 26, 274-285. [CrossRef] [PubMed]

84. Li, Y.; Xiao, K.; Luo, J.; Xiao, W.; Lee, J.S.; Gonik, A.M.; Kato, J.; Dong, T.A.; Lam, K.S. Well-defined, reversible disulfide cross-linked micelles for on-demand paclitaxel delivery. Biomaterials 2011, 32, 6633-6645. [CrossRef] [PubMed]

85. Bhattacharyya, S.; Saha, S.; Giri, K.; Lanza, I.R.; Nair, K.S.; Jennings, N.B.; Rodriguez-Aguayo, C.; Lopez-Berestein, G.; Basal, E.; Weaver, A.L.; et al. Cystathionine Beta-Synthase (CBS) Contributes to Advanced Ovarian Cancer Progression and Drug Resistance. PLoS ONE 2013, 8. [CrossRef] [PubMed] 
86. Szabo, C.; Coletta, C.; Chao, C.; Módis, K.; Szczesny, B.; Papapetropoulos, A. Tumor-derived hydrogen sulfide, produced by cystathionine- $\beta$-synthase, stimulates bioenergetics, cell proliferation, and angiogenesis in colon cancer. PNAS Pharmacol. 2013, 110, 12474-12479. [CrossRef] [PubMed]

87. Sen, S.; Kawahara, B.; Gupta, D.; Tsai, R.; Khachatryan, M.; Farias-eisner, R.; Chaudhuri, G. Role of cystathionine $\beta$-synthase in human breast Cancer. Free Radic. Biol. Med. 2015, 86, 228-238. [CrossRef] [PubMed]

88. Panza, E.; De Cicco, P.; Armogida, C.; Scognamiglio, G.; Gigantino, V.; Botti, G.; Germano, D.; Napolitano, M.; Papapetropoulos, A.; Bucci, M.; et al. Role of the cystathionine $\gamma$ lyase/hydrogen sulfide pathway in human melanoma progression. Pigment Cell Melanoma Res. 2015, 28, 61-72. [CrossRef] [PubMed]

89. Gai, J.W.; Qin, W.; Liu, M.; Wang, H.F.; Zhang, M.; Li, M.; Zhou, W.H.; Ma, Q.T.; Liu, G.M.; Song, W.H.; et al. Expression profile of hydrogen sulfide and its synthases correlates with tumor stage and grade in urothelial cell carcinoma of bladder. Urol. Oncol. Semin. Orig. Investig. 2016, 34. [CrossRef] [PubMed]

90. Pan, Y.; Zhou, C.; Yuan, D.; Zhang, J.; Shao, C. Radiation Exposure Promotes Hepatocarcinoma Cell Invasion through Epithelial Mesenchymal Transition Mediated by H2S/CSE Pathway. Radiat. Res. 2015, 185, 96-105. [CrossRef] [PubMed]

91. Schnelldorfer, T.; Gansauge, S.; Gansauge, F.; Schlosser, S.; Beger, H.G.; Nussler, A.K. Glutathione depletion causes cell growth inhibition and enhanced apoptosis in pancreatic cancer cells. Cancer 2000, 89, 1440-1447. [CrossRef]

92. Wang, R. Physiological Implications of Hydrogen Sulfide: A Whiff Exploration That Blossomed. Physiol. Rev. 2012, 92, 791-896. [CrossRef] [PubMed]

93. Módis, K.; Panopoulos, P.; Coletta, C.; Papapetropoulos, A.; Szabo, C. Hydrogen sulfide-mediated stimulation of mitochondrial electron transport involves inhibition of the mitochondrial phosphodiesterase 2A, elevation of cAMP and activation of protein kinase A. Biochem. Pharmacol. 2013, 86, 1311-1319. [CrossRef] [PubMed]

94. Fu, M.; Zhang, W.; Wu, L.; Yang, G.; Li, H.; Wang, R. Hydrogen sulfide (H2S) metabolism in mitochondria and its regulatory role in energy production. Proc. Natl. Acad. Sci. USA 2012, 109, 2943-2948. [CrossRef] [PubMed]

95. Olson, K.R.; DeLeon, E.R.; Gao, Y.; Hurley, K.; Sadauskas, V.; Batz, C.; Stoy, G.F. Thiosulfate: A readily accessible source of hydrogen sulfide in oxygen sensing. Am. J. Physiol. Regul. Integr. Comp. Physiol. 2013, 305, R592-R603. [CrossRef] [PubMed]

96. Cochrane, D.R.; Hughes, C.S.; Nazeran, T.; Karnezis, A.N.; McConechy, M.K.; Morin, G.B.; Huntsman, D.G. Abstract AP12: Cysteine metabolism in clear cell ovarian cancer. In Proceedings of the Ovarian Cancer Research Symposium, Seattle, WA, USA, 12-13 September 2016.

97. Poisson, L.M.; Munkarah, A.; Madi, H.; Datta, I.; Hensley-Alford, S.; Tebbe, C.; Buekers, T.; Giri, S.; Rattan, R. A metabolomic approach to identifying platinum resistance in ovarian cancer. J. Ovarian Res. 2015, 8. [CrossRef] [PubMed]

98. Okuno, S.; Sato, H.; Tamba, M.; Wang, H.; Sohda, S.; Hamada, H.; Yoshikawa, H. Role of cystine transport in intracellular glutathione level and cisplatin resistance in human ovarian cancer cell lines. Br. J. Cancer 2003, 951-956. [CrossRef] [PubMed]

99. Wang, W.; Kryczek, I.; Dostál, L.; Lin, H.; Tan, L.; Zhao, L.; Lu, F.; Wei, S.; Maj, T.; Peng, D.; et al. Effector T Cells Abrogate Stroma-Mediated Chemoresistance in Ovarian Cancer. Cell 2016, 165, 1092-1105. [CrossRef] [PubMed]

100. Mieyal, J.J.; Gallogly, M.M.; Qanungo, S.; Sabens, E.A.; Shelton, M.D. Molecular Mechanisms and Clinical Implications of Reversible Protein S-glutathionylation. Antioxid. Redox Signal. 2008, 10, 1941-1988. [CrossRef] [PubMed]

101. Emmanuel, C.; Chiew, Y.E.; George, J.; Etemadmoghadam, D.; Anglesio, M.S.; Sharma, R.; Russell, P.; Kennedy, C.; Fereday, S.; Hung, J.; et al. Genomic classification of serous ovarian cancer with adjacent borderline differentiates Ras pathway and TP53-mutant tumors and identifies NRAS as an oncogenic driver. Clin. Cancer Res. 2014, 20, 6618-6630. [CrossRef] [PubMed]

102. Van Jaarsveld, M.T.M.; van Kuijk, P.F.; Boersma, A.W.M.; Helleman, J.; van IJcken, W.F.; Mathijssen, R.H.J.; Pothof, J.; Berns, E.M.J.J.; Verweij, J.; Wiemer, E.A.C. miR-634 restores drug sensitivity in resistant ovarian cancer cells by targeting the Ras-MAPK pathway. Mol. Cancer 2015, 14, 1-13. [CrossRef] [PubMed]

103. Mackenzie, R.; Kommoss, S.; Winterhoff, B.J.; Kipp, B.R.; Garcia, J.J.; Voss, J.; Halling, K.; Karnezis, A.; Senz, J.; Yang, W.; et al. Targeted deep sequencing of mucinous ovarian tumors reveals multiple overlapping 
RAS-pathway activating mutations in borderline and cancerous neoplasms. BMC Cancer 2015, 15, 1-10. [CrossRef] [PubMed]

104. Zheng, G.F.; Cai, Z.; Meng, X.K.; Zhang, Y.; Zhu, W.; Pang, X.Y.; Dou, L. Unfolded protein response mediated JNK/AP-1 signal transduction, a target for ovarian cancer treatment. Int. J. Clin. Exp. Pathol. 2015, 8, 6505-6511. [PubMed]

105. Chen, R.; Ngan, H.; Chan, D. The AMPK/TAK1/NF-kB signaling axis is indispensable for modulating ovarian cancer cell metabolism and peritoneal metastases. In Proceedings of the 21st Research Postgraduate Symposium (RPS 2016), Hong Kong, China, 1-2 December 2016.

106. Carduner, L.; Picot, C.R.; Leroy-Dudal, J.; Blay, L.; Kellouche, S.; Carreiras, F. Cell cycle arrest or survival signaling through $\alpha \mathrm{V}$ integrins, activation of PKC and ERK1/2 lead to anoikis resistance of ovarian cancer spheroids. Exp. Cell Res. 2014, 320, 329-342. [CrossRef] [PubMed]

107. Al-Alem, L.F.; McCord, L.A.; Southard, R.C.; Kilgore, M.W.; Curry, T.E. Activation of the PKC Pathway Stimulates Ovarian Cancer Cell Proliferation, Migration, and Expression of MMP7 and MMP101. Biol. Reprod. 2013, 89, 1-7. [CrossRef] [PubMed]

108. Hajiahmadi, S.; Panjehpour, M.; Aghaei, M.; Shabani, M. Activation of A2b adenosine receptor regulates ovarian cancer cell growth: Involvement of Bax/Bcl-2 and caspase-3. Biochem. Cell Biol. 2015, 9, 1-9. [CrossRef] [PubMed]

109. Su, Y.; Gao, L.; Teng, L.; Wang, Y.; Cui, J.; Peng, S.; Fu, S. Id1 enhances human ovarian cancer endothelial progenitor cell angiogenesis via PI3K/Akt and NF-kappaB/MMP-2 signaling pathways. J. Transl. Med. 2013, 11. [CrossRef] [PubMed]

110. Echevarría-Vargas, I.M.; Valiyeva, F.; Vivas-Mejía, P.E. Upregulation of miR-21 in cisplatin resistant ovarian cancer via JNK-1/c-Jun pathway. PLoS ONE 2014, 9. [CrossRef] [PubMed]

111. Yang-Hartwich, Y.; Soteras, M.G.; Lin, Z.P.; Holmberg, J.; Sumi, N.; Craveiro, V.; Liang, M.; Romanoff, E.; Bingham, J.; Garofalo, F.; et al. P53 Protein Aggregation Promotes Platinum Resistance in Ovarian Cancer. Oncogene 2015, 34, 3605-3616. [CrossRef] [PubMed]

112. Wu, R.; Baker, S.J.; Hu, T.C.; Norman, K.M.; Fearon, E.R.; Cho, K.R. Type i to type II ovarian carcinoma progression: Mutant Trp53 or Pik3ca confers a more aggressive tumor phenotype in a mouse model of ovarian cancer. Am. J. Pathol. 2013, 182, 1391-1399. [CrossRef] [PubMed]

113. Visscher, M.; Arkin, M.R.; Dansen, T.B. Covalent targeting of acquired cysteines in cancer. Curr. Opin. Chem. Biol. 2016, 30, 61-67. [CrossRef] [PubMed]

114. Mohell, N.; Alfredsson, J.; Fransson, A.; Uustalu, M.; Byström, S.; Gullbo, J.; Hallberg, A.; Bykov, V.J.N.; Björklund, U.; Wiman, K.G. APR-246 overcomes resistance to cisplatin and doxorubicin in ovarian cancer cells. Cell Death Dis. 2015, 6, 1-11. [CrossRef] [PubMed]

115. Nunes, S.C.; Ramos, C.; Lopes-Coelho, F.; Sequeira, C.O.; Silva, F.; Gouveia-Fernandes, S.; Rodrigues, A.; Guimarães, A.; Silveira, M.; Abreu, S.; et al. Cysteine allows ovarian cancer cells to adapt to hypoxia and to escape from carboplatin cytotoxicity. Sci. Rep. 2018, in press. [CrossRef] [PubMed]

116. Nunes, S.C.; Lopes-Coelho, F.; Gouveia-Fernandes, S.; Ramos, C.; Pereira, S.A.; Serpa, J. Cysteine boosters the evolutionary adaptation to $\mathrm{CoCl}_{2}$ mimicked hypoxia conditions, favouring carboplatin resistance in ovarian cancer. BMC Evol. Biol. 2018, in press. [CrossRef] [PubMed]

(C) 2018 by the authors. Licensee MDPI, Basel, Switzerland. This article is an open access article distributed under the terms and conditions of the Creative Commons Attribution (CC BY) license (http://creativecommons.org/licenses/by/4.0/). 